\title{
Coprophilous histerids (Coleoptera: Histeridae) of the Polish Carpathians
}

\author{
Sławomir MAZUR ${ }^{1}$, Andrzej GóRz ${ }^{2}$ and Adam BYK ${ }^{3}$ \\ ${ }^{1}$ Institute of Forest Sciences, Branch of the University of Łódź, Konstytucji 3 Maja 65/67, 97-200 Tomaszów \\ Mazowiecki, Poland \\ ${ }^{2}$ Department of Invertebrate Zoology and Parasitology, Institute of Biology, Pedagogical University of Cracow, \\ Podbrzezie 3, 31-054 Kraków, Poland \\ ${ }^{3}$ Department of Forest Protection and Ecology, Warsaw University of Life Sciences - SGGW, Nowoursynowska \\ 159/34, 02-776 Warszawa, Poland; e-mail: adam_byk@sggw.pl
}

\begin{abstract}
The occurrence of coprophilous histerids in the Polish Carpathians was investigated. A total of 2,680 specimens, representing 11 species and 4 genera, were collected. The vertical distribution of individual species and their zoogeography was analysed.
\end{abstract}

Key words: Atholus, Hister, Margarinotus, Onthophilus, Carpathians, Poland

\section{INTRODUCTION}

The occurrence of histerids in the mountains of Poland has never been a specific subject of research. Scattered data, mainly from the nineteenth and the first half of the twentieth century, have been collected in Catalogue of Polish Fauna (Burakowski et al. 1978). This work also distinguished montane faunistic regions, including those that are part of the Polish Carpathians. Burakowski et al. (1978) report 57 histerid species from the Carpathians, 50 species from the Eastern Beskids, 45 species from the Western Beskids, three species from the Bieszczady Mountains, one from the Pieniny Mountains, and four from the Tatra Mountains. The poor state of knowledge of the histerid fauna of Polish mountain ranges is evidenced by the recent finding of Margarinotus striola succicola (C.G. Thomson, 1862), a new species for the fauna of the Bieszczady Mountains (Kubisz et al. 1998), or Platysoma angustatum (Hoffmann, 1803) and Plegaderus vulneratus (Panzer, 1797), new species for the fauna of the Tatra Mountains (Tykarski 2006).

A critical analysis of these data by Tykarski \& Knutelski (2010), supported by their own research, enabled them to compile a relatively accurate list of the beetles of the Tatras, including 6 histerid species. Pawłowski et al. (2000), in a study of the beetles of the Western Bieszczady Mountains, recorded 10 histerid species. The remaining mountain ranges have yet to be critically summarized in this way. It is also difficult to find comparable data from other mountainous regions of Europe. One study could be mentioned here (Penati 1997), in which 32 species were reported from mountainous regions of northern Italy (Province of Sondrio, Lombardy). This situation can be explained in part by the fact that among histerids inhabiting Europe there are no typically boreal or boreal-montane species, and thus the higher parts of mountains are very poor in species (Mazur 1981).

The present study will therefore significantly expand our knowledge of histerids occurring in the mountains of Poland. 


\section{MATERIAL AND METHODS}

\section{Study area}

Region of the Polish Carpathians are characterized by a highly varied natural environment. For this reason 50 sites were selected for the investigation of coprophilous Histeridae, taking into account both the horizontal variability and the altitude variability (Table 1, Fig. 1).

Table 1. List of sites in the Polish Carpathians where research was conducted on coprophilous Histeridae

\begin{tabular}{|c|c|c|c|}
\hline Macroregion & No. on map/Site & Elevation (m a.s.l.) & Vegetation belt \\
\hline \multirow{6}{*}{ TATRAS } & 1. Twarda Galeria & 1,776 & Alpine \\
\hline & 2. Upłaziańska Kopa & 1,449 & Subalpine \\
\hline & 3. Skupniów Upłaz & 1,390 & Upper montane range \\
\hline & 4. Polana Kopieniec & 1,236 & Upper montane range \\
\hline & 5. Kuźnice & 1,000 & Lower montane range \\
\hline & 6. Dolina Kościeliska & 980 & Lower montane range \\
\hline \multirow{3}{*}{ PODHALE } & 7. Harklowa & 569 & Lower montane range \\
\hline & 8. Biała Woda & 771 & Lower montane range \\
\hline & 9. Sromowce Niżne & 584 & Lower montane range \\
\hline \multirow{12}{*}{ BIESZCZADY } & 10. Tarnica & 1,322 & Subalpine meadows (Poloninas) \\
\hline & 11. Poł. Caryńska & 1,283 & Subalpine meadows (Poloninas) \\
\hline & 12. Przełęcz Bukowska & 1,117 & Upper montane range \\
\hline & 13. Brzegi Górne & 773 & Lower montane range \\
\hline & 14. Tarnawa & 677 & Lower montane range \\
\hline & 15. Łopienka / Buk & 592 & Lower montane range \\
\hline & 16. Michniowiec & 591 & Lower montane range \\
\hline & 17. Buk / Cisna & 533 & Lower montane range \\
\hline & 18. Kalnica & 471 & Foothills \\
\hline & 19. Serednica & 454 & Foothills \\
\hline & 20. Paszowa & 439 & Foothills \\
\hline & 21. Stefkowa & 406 & Foothills \\
\hline \multirow{16}{*}{ EASTERN BESKIDS } & 22. Ciechań & 629 & Lower montane range \\
\hline & 23. Żydowskie & 499 & Foothills \\
\hline & 24. Nieznajowa & 462 & Foothills \\
\hline & 25. Rozstajne & 452 & Foothills \\
\hline & 26. Kąty & 437 & Foothills \\
\hline & 27. Stasiówka & 395 & Foothills \\
\hline & 28. Krempna & 386 & Foothills \\
\hline & 29. Polichty & 362 & Foothills \\
\hline & 30. Huwniki & 361 & Foothills \\
\hline & 31. Tarnowiec & 354 & Foothills \\
\hline & 32. Borowa & 330 & Foothills \\
\hline & 33. Gorlice & 302 & Foothills \\
\hline & 34. Pleśna & 263 & Foothills \\
\hline & 35. Folusz & 262 & Foothills \\
\hline & 36. Kołaczyce & 218 & Foothills \\
\hline & 37. Jasło & 213 & Foothills \\
\hline \multirow{13}{*}{ WESTERN BESKIDS } & 38. Przehyba & 1,133 & Upper montane range \\
\hline & 39. Przeł. Krowiarki & 1,058 & Lower montane range \\
\hline & 40. Hala Boracza & 863 & Lower montane range \\
\hline & 41. Lubomierz & 768 & Lower montane range \\
\hline & 42. Żabnica & 736 & Lower montane range \\
\hline & 43. Uhryń & 713 & Lower montane range \\
\hline & 44. Kocoń & 630 & Lower montane range \\
\hline & 45. Kamesznica & 626 & Lower montane range \\
\hline & 46. Gaboń & 488 & Foothills \\
\hline & 47. Kamienica & 475 & Foothills \\
\hline & 48. Rytro & 452 & Foothills \\
\hline & 49. Naszacowice & 342 & Foothills \\
\hline & 50. Gołkowice Dolne & 317 & Foothills \\
\hline
\end{tabular}




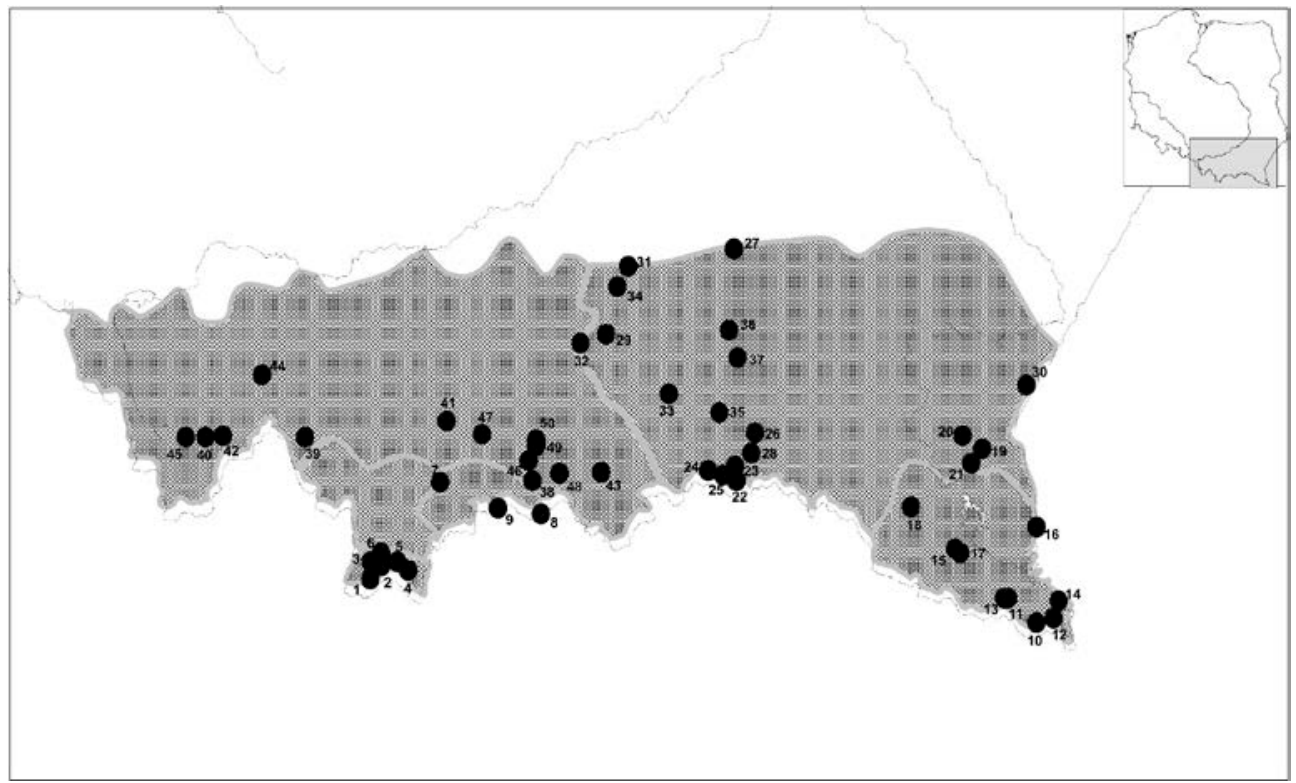

Fig. 1. Location of the study sites in the Polish Carpathians.

\section{Materials}

The research was conducted every year from the beginning of May until the end of October in the years 2011-2013 at fifty sites in the Polish Carpathians (Fig. 1). Baited traps were used to collect coprophilous beetles (Fig. 2).

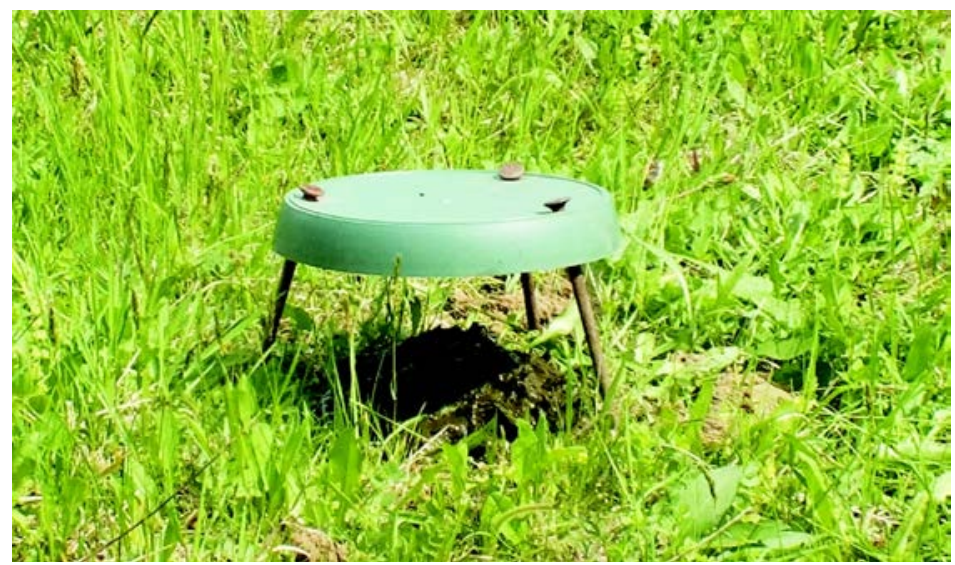

Fig. 2. Dung beetle traps used in the studies. Photo by A. Górz.

Traps were constructed from plastic tube containers, $20 \mathrm{~cm}$ high and $17 \mathrm{~cm}$ wide, filled with ethylene glycol as a preservative (approx. $200 \mathrm{ml}$ ). The tubes were buried in the soil with their rim at ground level and covered with $15 \mathrm{~mm}$ thick wire mesh with approx. $800 \mathrm{~g}$ of fresh cow dung placed on it. All traps were protected from rain by the round lid ( $25 \mathrm{~cm}$ diameter), which was fixed to the ground with nails. For each site three traps arranged in a triangle were set up at $10 \mathrm{~m}$ intervals. The traps were emptied once every 10-12 days. 


\section{RESULTS}

During the study carried out in 2011-2013 in the Polish Carpathians 2,680 coprophilous histerid individuals were collected, representing 11 species and 4 genera. The genera Atholus C.G. Thomson, 1859 and Onthophilus Leach, 1817 were represented by one species each, the genus Hister Linnaeus, 1758 by 2 species, and the genus Margarinotus Marseul, 1854 by 7 species. The species caught in the highest numbers were Hister unicolor unicolor Linnaeus, 1758 (85.5\%), Margarinotus striola succicola (5.2\%) and Margarinotus carbonarius carbonarius (Hoffmann, 1803) (4.1\%). Two of the species caught are very rarely encountered in Poland: Hister funestus Erichson, 1834 and Onthophilus striatus (Forster, 1771) (Table 2).

Table 2. Coprophilous histerids (Coleoptera: Histeridae) caught in baited traps in the Polish Carpathians in 2011-2013; *-refers to species not recorded for a given region according to Catalogue of Polish Fauna (Burakowski et al. 1978).

\begin{tabular}{|c|c|c|c|c|c|c|c|c|}
\hline No. & Species & 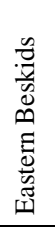 & 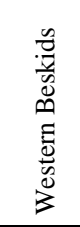 & 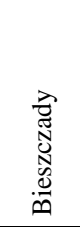 & 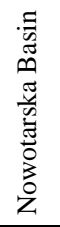 & 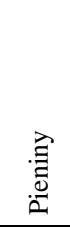 & $\underset{\tilde{E}}{\tilde{E}}$ & 퐁 \\
\hline 1 & Atholus duodecimstriatus duodecimstriatus (Schrank, 1781) & & 5 & 3 & & & & 8 \\
\hline 2 & Hister funestus Erichson, 1834 & & $2 *$ & $1^{*}$ & & & & 3 \\
\hline 3 & Hister unicolor unicolor Linnaeus, 1758 & 272 & 1,578 & $292 *$ & $2 *$ & $119 *$ & 28 & 2,291 \\
\hline 4 & Margarinotus brunneus (Fabricius, 1775) & 1 & & & & & & 1 \\
\hline 5 & Margarinotus carbonarius carbonarius (Hoffmann, 1803) & 11 & 55 & $2 *$ & $1 *$ & $39 *$ & & 108 \\
\hline 6 & Margarinotus merdarius (Hoffmann, 1803) & & 1 & & & & & 1 \\
\hline 7 & Margarinotus obscurus (Kugelann, 1792) & & 1 & & & & & 1 \\
\hline 8 & Margarinotus striola succicola (C.G. Thomson, 1862) & 5 & 117 & $8 *$ & & & $8 *$ & 138 \\
\hline 9 & Margarinotus terricola (Germar, 1824) & & 3 & $2 *$ & & & 1 & 6 \\
\hline 10 & Margarinotus ventralis (Marseul, 1854) & 7 & 59 & $12 *$ & & $4^{*}$ & & 82 \\
\hline \multirow[t]{2}{*}{11} & Onthophilus striatus (Forster, 1771) & & 41 & & & & & 41 \\
\hline & Total & 296 & 1,862 & 320 & 3 & 162 & 37 & 2,680 \\
\hline
\end{tabular}

Margarinotus brunneus and M. obscurus were noted up to an altitude of $600 \mathrm{~m}$ a.s.l.; Atholus duodecimstriatus, Hister funestus, Margarinotus carbonarius, M. merdarius and Onthophilus striatus up to 900 m a.s.l.; Margarinotus striola succicola, M. terricola and M. ventralis up to 1,500 m a.s.l.; and only Hister unicolor up to 1,800 m a.s.l. (Fig. 3).

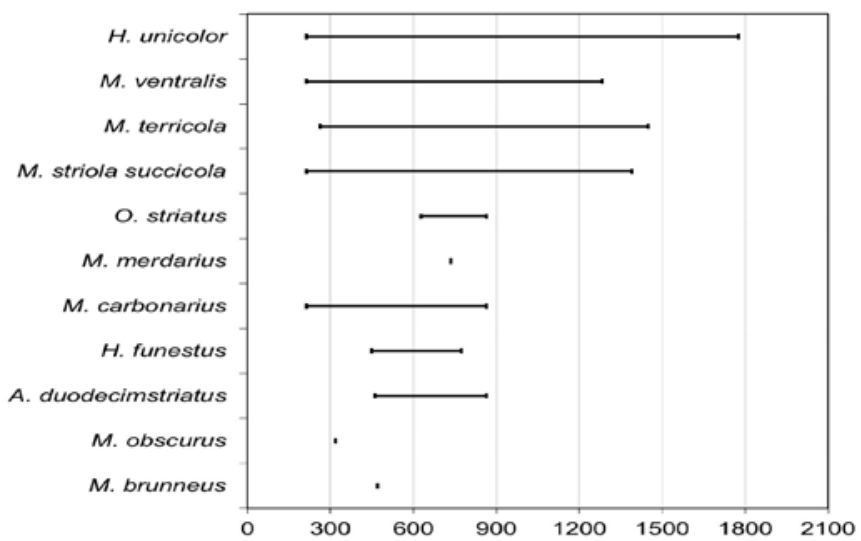

Fig. 3. Vertical range of coprophilous histerids (Coleoptera: Histeridae) in the Polish Carpathians. 


\section{Onthophilus striatus (Forster, 1771)}

Inhabits nearly all of Europe, as well as the Caucasus and Asia Minor. Highly localized in Poland, recorded from mountainous regions only in the Western Sudetes and Barania Góra (BURAKOWSKI et al. 1978). Noted in recent years in Babia Góra (Kubisz \& Szafraniec 2001), the Wielkopolsko-Kujawska Lowlands (Ruta et al. 2004), and the military training ground in Biedrusko (Bajerlein et al. 2011). Caught in northern Italy at an elevation of $550 \mathrm{~m}$ a.s.l. (Penati 1997).

Caught during the study in the Western Beskids: Żywiec Beskids (Hala Boracza, $863 \mathrm{~m}$ a.s.l., Żabnica, 736 m), Silesian Beskids (Kamesznica, 626 m.), and Little Beskids (Kocoń, 630 m).

\section{Margarinotus brunneus (Fabricius, 1775)}

Palearctic species, ranging eastward to Yakutia and Lake Baikal and to Kazakhstan and the mountains of Central Asia; also introduced to the east coast of North America. Recorded several times in mountainous regions of Poland (Burakowski et al. 1978).

Caught only in the Eastern Beskids: Western Bieszczady (Kalnica, 471 m a.s.l.).

\section{Margarinotus carbonarius (Hoffmann, 1803)}

Europe, the Caucasus, and Siberia eastward to the Altai Mountains. Common in Poland. Recorded in the Western and Eastern Sudetes and Western and Eastern Beskids (Burakowski et al. 1978).

Caught during the study in nearly all ranges of the Western Beskids and the Pieniny Mountains in the elevation range of 213-863 m.

\section{Margarinotus merdarius (Hoffmann, 1803)}

Nearly all of Europe, northern Africa, Iran, and North America. Fairly rare in Poland, from mountainous regions noted in the Eastern and Western Sudetes and the Western Beskids (Burakowski et al. 1978). Caught in northern Italy in the 230-860 m altitude range (Penati 1997).

Caught in the Western Beskids: Żywiec Beskids (Żabnica, 736 m a.s.1.).

\section{Margarinotus obscurus (Kugelann, 1792)}

Distributed in Europe, northern Africa, Asia Minor, the Caucasus, Iran and China. Introduced to the western US and Canada. Not very common in Poland, recorded in the Sudetes and Beskids (Burakowski et al. 1978).

Caught only in the Western Beskids: Beskid Sądecki (Gołkowice Dolne, 317 m a.s.l.).

\section{Margarinotus striola succicola (C.G. Thomson, 1862)}

Subspecies known in Europe and western Siberia; common all over Poland. From mountainous regions noted in the Western Sudetes, the Western and Eastern Beskids and the Pieniny Mountains (Burakowski et al. 1978).

One of the most numerous species in the altitude range of 213-1,390 m (see Table 2).

\section{Margarinotus terricola (Germar, 1824)}

Central and southern Europe, the Caucasus, Asia Minor, Iran. Rare in Poland, from mountains noted in the Sudetes and Beskids and in the Tatras (Burakowski et al. 1978). In mountainous regions of northern Italy caught between 630 and 1,850 m (Penati 1997).

Caught in small numbers in the Western Beskids: Ciężkowickie Foothills (Borowa, $320 \mathrm{~m}$ a.s.1.), Low Beskids (Folusz, $262 \mathrm{~m}$ ), Bieszczady (Lopienka, $592 \mathrm{~m}$, Tarnica, 1,322 m) and Tatras (Upłazińska Kopa, 1,449 m). 


\section{Margarinotus ventralis (Marseul, 1854)}

Species known from Europe, Asia Minor and western Siberia. Fairly frequent in Poland, noted in the Sudetes and Beskids (Burakowski et al. 1978).

Caught at nearly all sites. Caught in the elevation range of 213-1,283 m.

\section{Hister funestus Erichson, 1834}

Species known from central and northern Europe, the Caucasus, western Siberia, northeastern Kazakhstan and the mountains of Central Asia. Very rare in Poland, known from a small number of scattered sites, including mountainous areas (Eastern Sudetes) (Burakowski et al. 1978). Recently found in Podlasie (Byk et al. 2014).

Caught only in the Low Beskids (Żydowskie, 449 m a.s.1.) and Bieszczady (Brzegi Górne, $773 \mathrm{~m})$.

\section{Hister unicolor unicolor Linnaeus, 1758}

Euro-Siberian species, recorded in Europe, the Caucasus and Siberia eastward up to the Baikal. Common in Poland, found in both lowland and upland areas (Burakowski et al. 1978). In northern Italy caught at elevations of 200-1,850 m (Penati 1997).

Caught at nearly all sites, dominant among coprophilous histerids. Caught in the elevation range of $213-1,776 \mathrm{~m}$.

\section{Atholus duodecimstriatus duodecimstriatus (Schrank, 1781)}

Known from northern Africa, western and central Europe, the Caucasus and Afghanistan. Localized in Poland, also noted in the mountains (Burakowski et al. 1978). Caught in Lombardy at an altitude of 200-1,850 m (Penati 1997).

Caught in small numbers in the Bieszczady Mountains (Łopienka, $592 \mathrm{~m}$ a.s.l.), Żywiec Beskids (Hala Boracza, $863 \mathrm{~m}$ ) and Low Beskids (Nieznajowa, $462 \mathrm{~m}$, Żydowskie, $499 \mathrm{~m}$ ).

\section{DISCUSSION}

During the three-year study in mountainous regions of Poland 11 coprophilous histerid species were caught, represented by 2,680 specimens. The most species (9) were caught in the 600-900 m elevation range, while only one species, Hister unicolor unicolor, was noted in the 1,500-1,800 $\mathrm{m}$ range. All species recorded during the study had previously been noted from the lowland and upland parts of the country, and with the exception of Hister funestus, from the Baltic Coast as well (Burakowski et al. 1978). This confirms the proposition that there are no typical montane species among Polish histerids. Pawłowski et al. (2000) indicate the presence of 10 species of the Histeridae family in the Western Bieszczady three species reported by Burakowski et al. (1978) and seven by Kubisz et al. (1998); none of these were species occurring primarily in mountains.

Euro-Caucasian species are dominant here (4 species: Hister funestus, Margarinotus terricola, $M$. ventralis and Onthophilus striatus). Species of this group are generally not found beyond an altitude of $900 \mathrm{~m}$; only Margarinotus terricola and M. ventralis were caught in the 1,200-1,500 $\mathrm{m}$ range. The areas occupied by this group correspond with the range of broadleaf forests, and in the Polish mountains do not extend beyond the boundaries of the lower montane belt. Three species (Margarinotus brunneus, M. merdarius and M. obscurus) represent Holarctic taxa, and their vertical range does not exceed $900 \mathrm{~m}$. There are two Euro-Siberian species: Hister unicolor unicolor and Margarinotus striola succicola. Both are abundant throughout the elevation range, reaching the upper montane belt 
(M. striola succicola) or the subalpine belt (Hister unicolor unicolor). This confirms that Euro-Siberian species are the most ecologically flexible group; they are extremely well adapted to changing environmental conditions (Mazur 1981). In the mountains of Lombardy $H$. unicolor unicolor also dominated all species recorded in terms of abundance (Penati 1997). Atholus duodecimstriatus duodecimstriatus, a Palearctic species, was not found beyond the boundaries of the lower montane belt. The Boreal-Pontic species Margarinotus carbonarius was among the species caught in the highest numbers (108 specimens), occurring optimally in the foothills and lower montane belt. Boreal-Pontic species are associated more with steppe areas, but due to their high resistance to cold they can even reach the edge of the tundra.

All species caught belong to one of two subfamilies: Histerinae and Onthophilinae. There is a striking lack of representatives of the subfamily Saprininae, which certainly includes coprophilous species and which constitutes the dominant group of necrophilous and coprophilous histerids in lowlands (Bajerlein et al. 2011).

\section{ACKNOWLEDGEMENTS}

We thank Sara Wild for his help in the English revision of the manuscript. This study was financially supported by Ministry of Science and Higher Education grant number N N304 139940).

\section{REFERENCES}

Bajerlein D., MatuszewsKi Sz. \& Konwerski Sz. 2011. Insect succession on carrion: seasonality, habitat preference and residency of histerid beetles (Coleoptera: Histeridae) visiting pig carrion exposed in various forest (Western Poland). Polish Journal of Ecology 59 (4): 787-797.

BurakowsKi B., MroczKowsKi M. \& StefańSKA J. 1978. Histeroidea i Staphylinoidea prócz Staphylinidae. Chrząszcze - Coleoptera. Katalog Fauny Polski 23 (5): 1-356.

Byk A., MAzUr S. \& Nesterowicz Ł. 2014. New localities of Hister funestus ERICHSON, 1834 and Hister illigeri Duftschmid, 1805 (Coleoptera: Histeridae) in Poland. Wiadomości entomologiczne 33 (4): 284-285.[in Polish with English abstract]

KuBISZ D. \& SzAFRANIEC S. 2001. Interesting beetles found in the Babia Góra massif, the West Carpathians Mts. (Coleoptera). Acta entomologica silesiana 7-8: 43-48. [in Polish with English Abstract]

Kubisz D., Szwatko P. \& WojAs T. 1998. Materials to the fauna of Coleoptera of the Western Bieszczady Mts. (Polish Eastern Carpathians). Rocznik Muzeum Górnośląskiego (Przyroda) 15: 5-15.

MAZUR S. 1981. Histeridae - gnilikowate (Insecta: Coleoptera) [Histeridae - histerids (Insecta: Coleoptera)]. Fauna Polski 9: 1-205.

PawŁowski J., Petryszak B., Kubisz D. \& SzwaŁko P. 2000. Chrząszcze (Coleoptera) Bieszczadów Zachodnich. Monografie Bieszczadzkie 8: 9-143.

PENATI F. 1997. Checklist of the Histeridae (Insecta, Coleoptera) of the Province of Sondrio (Lombardy, Northern Italy). Il Naturalista Valtellinese 8: 43-94. [in Italian with English abstract]

RutA R., JAŁOSZYŃSKi P. \& KoNWERSKi Sz. 2004. New records of the histerid beetles (Coleoptera: Histeridae) in Poland. Part 1. Onthophilinae - Dendrophilinae. Wiadomości entomologiczne 23(1): 13-20. [in Polish with English abstract]

TYKARSKI P. 2006. Beetles associated with scolytids (Coleoptera, Scolytidae) and the elevational gradient: Diversity and dynamics of the community in the Tatra National Park, Poland. Forest Ecology and Management 225: $146-159$. doi:10.1016/j.foreco.2005.12.034

TYKARSKI P. \& KNUTELSKI S. 2010. Beetles of the Tatra Mountains - current state of the knowledge and perspectives for the future research (Insecta: Coleoptera). Wiadomości entomologiczne 29 (Supl.): 89-101. [in Polish with English abstract]

\section{STRESZCZENIE}

\section{[Koprofilne gniliki (Coleoptera: Histeridae) polskiej części Karpat]}

W trakcie 3-letnich badań na terenie polskich Karpat odłowiono 2680 okazów należących do 11 gatunków koprofilnych gnilików. Wszystkie odłowione gatunki należą do dwóch 
podrodzin: Histerinae i Onthophilinae. Natomiast nie stwierdzono przedstawicieli podrodziny Saprininae. Największą liczbę gatunków (9) odłowiono na stanowiskach znajdujących się w przedziale wysokości od 600 do 900 m n.p.m.. Natomiast na wysokościach od 1500-1800 m n.p.m. odłowiono tylko jeden gatunek. Wszystkie stwierdzone gatunki były wcześniej notowane $\mathrm{z}$ nizinnej i wyżynnej części kraju, co potwierdza opinię o braku typowych elementów górskich wśród krajowych gnilików.

Cztery gatunki spośród stwierdzonych, tj. Hister funestus, Margarinotus terricola, M. ventralis, Onthophilus stratus, zoogeograficznie reprezentują element eurokaukaski, trzy gatunki (Margarinotus brunneus, M. merdarius, M. obscurus) - element holarktyczny, natomiast element eurosyberyjski jest reprezentowany przez dwa gatunki: Hister unicolor i Margarinotus striola succicola. Oba występują licznie w szerokim przedziale wysokości, do regla górnego (M. striola succicola) bądź piętra kosodrzewiny (Hister unicolor). Potwierdza to opinię, że gatunki eurosyberyjskie są najbardziej plastyczną ekologicznie grupą, doskonale przystosowującą się do zmieniających się warunków środowiskowych.

Dwa odłowione gatunki Hister funestus i Onthophilus striatus są bardzo rzadko spotykane w naszym kraju. 